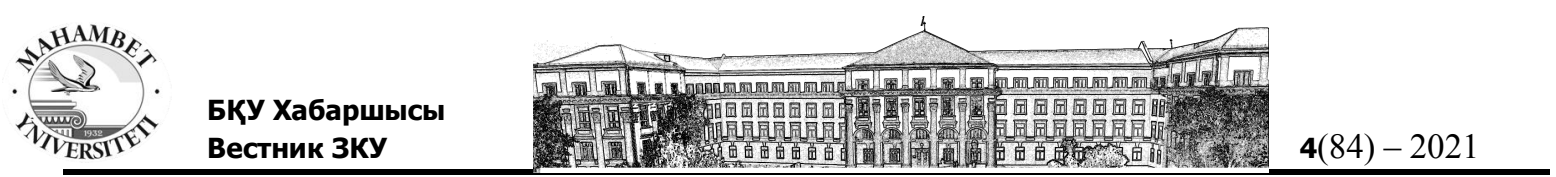

УДК 551.247.1 (574.1)

МРНТИ 39.19 .31

DOI $10.37238 / 1680-0761.2021 .84(4) .48$

\author{
Ахмеденов К.М.* \\ Западно-Казахстанский университет им. М.Утемисова, г.Уральск, Казахстан \\ *Автор-корреспондент: kazhmurat78@mail.ru \\ E-mail: kazhmurat78@mail.ru

\section{ЕСТЕСТВЕННЫЕ ГАЗОВЫЕ ВЫХОДЫ ОЗЕРА УЛКЕН ТУЗДЫ САРКЫЛ ЗАПАДНО-КАЗАХСТАНСКОЙ ОБЛАСТИ}

\begin{abstract}
Аннотация. На базе литературных и натурных данных изучены естественные газовые выходы в пределах озера Улкен Тузды Саркыл Казталовского района ЗападноКазахстанской области, расположенного в северной части Прикаспийской низменности и имеющего непостоянный уровень. Дана характеристика 7 газовых выходов на западном острове озера Улкен Тузды Саркыл. Выявлень состав растительных сообществ, особенности гидрохимического состава и минерализащии вод газовых выходов. В составе газов, выделявшихся с данных газовых выходов, главным компонентом был метан $c$ некоторой примесью азота. Вода из газового выхода №1 является слабощелочной, относится $\kappa$ классу соленые $\kappa$ подклассу слабосоленые. Хлоридно-гидрокарбонатнонатриево-магниевый и хлоридно-натриево-магниевый тип минерализации воды указывает на то, что высокоминерализованные воды по формированию химического состава связаны с процессами континентального засоления. В пределах газовых выходов получили распространение галофильные и гипергалофильные растительные сообщества.

Показана особенности формирования примитивных ландшафтов газовых выходов в условиях аридного климата. Формирование ландшафтов на газовых выходах происходит в зависимости от наличия дебита и солености воды, затопления соров в весенний период и высыхания в летний.
\end{abstract}

Ключевые слова:естественные газовые выходы;газы;газопроявления;соленое озеро;солончак;галофильные растительные сообщества; минерализация; ландшафт; однолетнесолянковые сообщества; гидрохимия.

\title{
Введение
}

Люди использовали нефть и газ с древних времен там, где наблюдались их естественные выходы на поверхность земли. Такие выходы отмечаются и в настоящее время.Наиболее часто встречаются выходы природного газа - от едва заметных пузырьков до мощных фонтанов. На влажной почве и на поверхности воды небольшие газовые выходы фиксируются по появляющимся на них пузырькам. При фонтанных же выбросах, когда вместе с газом извергаются вода и горная порода, на поверхности остаются грязевые конусы высотой от нескольких до сотен метров. Конусы из грязи, образовавшиеся при периодических выбросах газа, встречаются в Азербайджане, на севере Ирана, в Мексике, Румынии, США,Колумбии, о. Тринидад, Италии, Украине, Туркменистане, Пакистане, Бирме, Малайзии и других странах [1-2].

Газопроявление - свободное постоянное, периодическое или пульсационноспонтанное (внезапное) поступление природных газов из недр на дневную поверхность, морское дно или в горные выработки [3]. Вопросы распределения, генезиса и других 
научных аспектов, связанных с газопроявлениями на суше и потоками природных газов в Мировом океане и его континентальном обрамлении: низкотемпературными сипами, газогидротермами, потоками газов из угленосных толщ, грязевыми вулканами и особенно газогидратами, отражены во многих публикациях [3-7].Выходы газов встречаются в океанах, морях и пресноводных водоемах. Имеются материалы о газопроявлениях на озере Байкале [5-7], сведения о естественных выходах газа и газопроявлениях в скважинах в междуречье Волги и Урала (Жайыка) опубликованы во многих работах[8-13].

Газопроявления сходы с процессами грязевого вулканизма, в том числе и на дне Каспийского моря.Следует отметить, что грязевой вулкан - это геологическое образование, постоянно или периодически извергающее на поверхность земли грязевые массы и газы, часто с водой или нефтью. Они присутствуют главным образом в нефтеносных и вулканических областях, встречаются в междуречье Волги и Урала. На восточном побережье Каспия около 30 вулканов. Они приурочены к побережью Казахстана - полуострову Бузачи и к урочищам Кайдак, Мертвый Култук, Прорва [13].

Иногда газопроявления совмещены с водными источниками.Естественный выход подземных вод на земную поверхность называют источником. В сущности, источник - это естественное вскрытие подземных вод. Восходящие источники образуются при выходе на поверхность напорных вод. Движение воды к источникам направлено снизу вверх. Восходящий источник можно определить по колебанию в выходящей струе взвешенных песчинок, а также по выделению пузырьков воздуха и газов[14].

Естественные газовые источники приурочены к соленым озерам. Местному населению с давних пор были известны «священные огни» - места, где из-под земли вместе с водой с шумом вырывались горючие газы. Эти места долгое время служили предметом поклонения местных жителей [15-18].

Франц Фёдорович Шперк (1835-1906), русский врач - климатолог, публицист и географ, в 1885-1889 гг. занимавшийся этнографией национальных меньшинств в Астраханской губернии и сотрудничавший с Ф.А. Брокгаузом и И.А. Ефроном, разместил в их энциклопедическом словаре статью "Букеевская или внутренняя киргизская орда" [19], отрывок из которой с описанием соленых озер приводится ниже: «... В степи имеется немало соленых озер, каковы, например: в Таловской части - Большой и Малый Сакрыль, с которых добывается ныне соль; в 1-м приморском округе - Чулан, из которого ранее добывалась соль; во 2-м округе - Баш-Чоко; в Калмыцкой части - Батырбек...».

В качестве озер с лечебной грязью и мест добычи соли Семенов В.П. (1903) [20] описывает озера Индер, Чорхал, Кара-Батан, Усть-Кемпир, Искене, Кара-Баспак, Чамбар, Ак-Кыз, Телюген, ТентякКалкаманское, Кызыл-Как, Муялды и другие. Семенов В.П. указывает, что: «Лечебными минеральными источниками и грязями Киргизский край довольно богат, но малонаселенность и невысокая культурность края мешают воспользоваться ими в нужной мере...В настоящее время правильной эксплуатации даже наиболее известных источников и грязей не существуют. Их посещают небольшое число больных, из которых большинство - киргизы...».

В 1928 году опубликована работа Н.Н.Тихоновича [21], посвященная описанию известных в то время выходов газа в Нижнем Заволжье, в которой приведены анализы проб газа из естественных выходов в районе озера Большой Соленый Сакрыл. В 1928 году А.А.Черепенников [11] посетил газовые выходы в районе Новой Казанки, в том числе описал и отобрал пробы газа из естественных газопроявлений озера Большой Соленый Сакрыл. С.М. Киселев в 1935 году [10] обобщил результаты собственных исследований и литературные данные по газопроявлениям на территории Северного Прикаспия, в том числе по озеру Большой Соленый Сакрыл.

Задача настоящей публикации - дополнение и обобщение данных о газовых выходах на озере Улкен Тузды Саркыл, выявление их ландшафтной значимости. 


\section{Материальь и методы}

Исследование проводилось в пределах озера Улкен Тузды Саркыл Казталовского района Западно-Казахстанской области [22]. Озеро Улкен Тузды Саркыл (4947'47"N 49²'9"Е) расположено в северной части Прикаспийской низменности (в междуречье рек Караозен и Сарыозен), представляющей собой наклоненную к югу пологую равнину, осложненную сухими руслами, широкими балками, озерными котловинами, элементами солянокупольной тектоники [23] (рис.1).

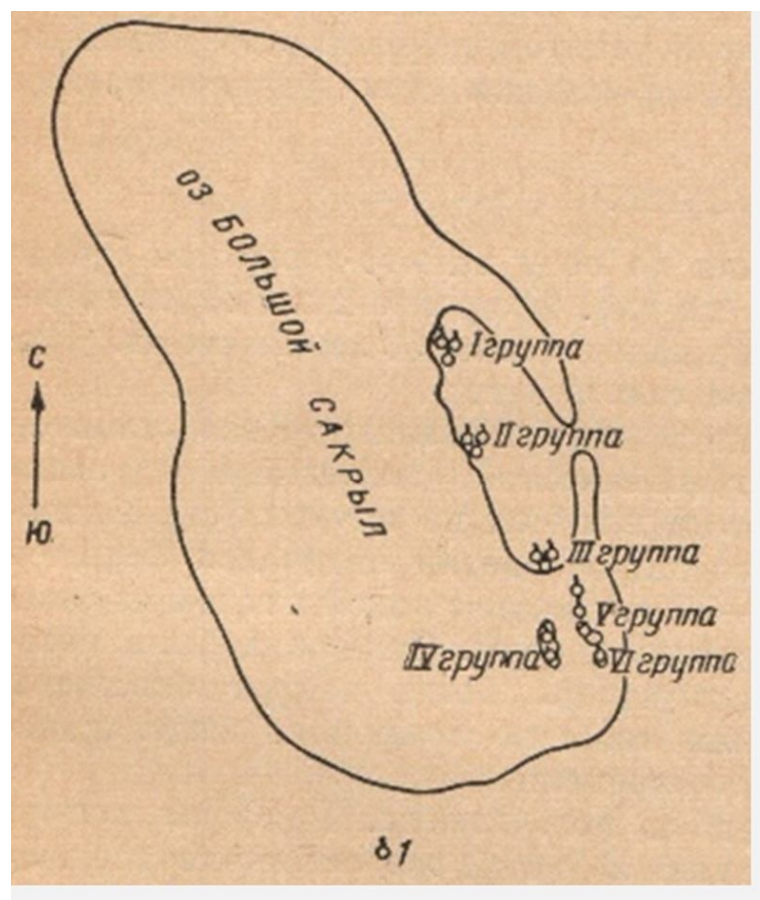

A

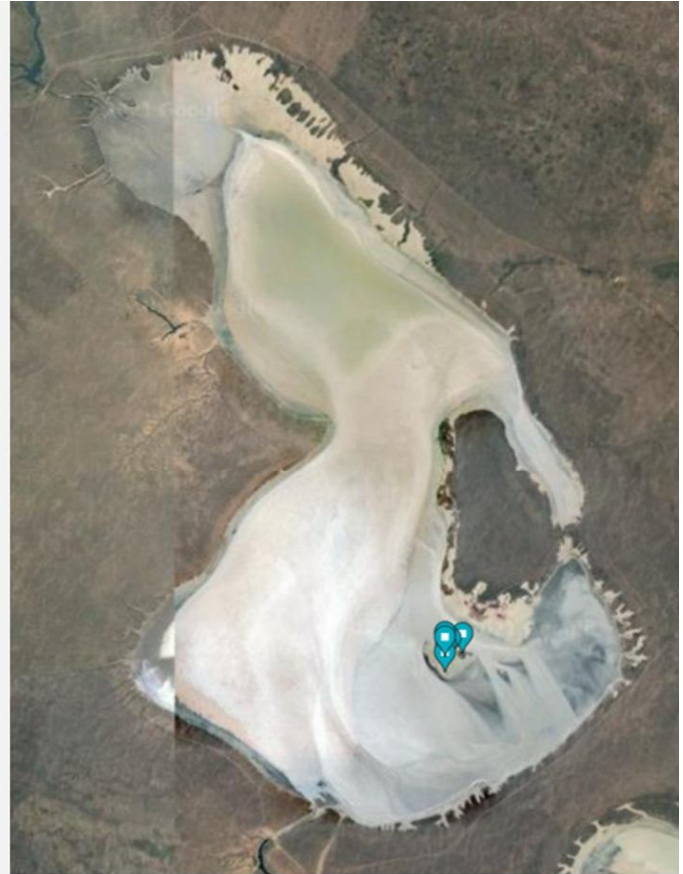

Б

Рисунок 1 - Схема расположения газовых выходов на оз. Улкен Тузды Саркыл: A - по Васильеву Ю.М., Обрядчикову О.С. [15]; Б- на космоснимке Google

По-видимому, это структурный сор, образование которого связано с компенсационной мульдой, сопровождающейсоляной купол, весной сор - это солоноватое маловодное озеро; летом большая ее часть мелеет и резкозасоляется; частично пересыхает, превращаясь в соленыетопи и солончаки [24]. Береговая линия на топографических картах обозначается горизонталью +10 м. Согласно геоморфологическому районированию озеро Улкен Тузды Саркыл располагается на Узенско-Чижинской системе разливов бессточных рек на Узенской водораздельной равнине, плоская поверхность которой характеризуется довольно значительным распространением замкнутых небольших лиманов и отдельных впадин соленых и пресных озер $[24,25]$. Питание озера осуществляется, в основном, за счет атмосферных осадков. Имея большой водосбор, оно заполняется весной, после таяния снега, но к лету большая часть его дна освобождается от воды и представляет собой мокрый солончак. Климат территории резко континентальный с жарким, засушливым летом, морозной зимой и сильными ветра.Исследуемая территория входит в зонуполупустынь со светло-каштановыми и бурыми почвами и злаково-полыннойрастительностью $[24,26]$.

Объектом исследования служили газовые выходы на озере Улкен Тузды Саркыл Прикаспийской низменности.Для изучения состояния газовых выходов и определения их морфометрических показателей применены дистанционные методы. Проведен анализ тематических карт, специальной литературы, космических снимков Landsat 8 (2021г.),, 
авторских данных полевых исследований газовых выходов на озере Улкен Тузды Саркыл Казталовского района Западно-Казахстанской области (2021 г.) (рис.1).

Для оценки морфометрических параметров и состояния газовых выходов также проведена видео-фотосъемка с высоты с помощью квадракоптераDJI Phantom 3 Standard (SZ DJI TechnologyCo., Ltd., Китай, 2017 г.). Фотосъемка объектов исследований проведена на цифровой зеркальной фотокамере NikonD500 (Nikon, Япония, 2015 г.). Координаты объектов фиксировали с помощью GPS-навигатора GarmineTrexH (GarminLtd., Тайвань, 2008 г.).

Лабораторный анализ химического состава воды был проведен в аккредитованной испытательной лаборатории экологии и биогеохимии НАО «Западно-Казахстанский университет имени М.Утемисова» (Аттестат аккредитации KZВ592СС3378359946№ KZ.И.09.1186 от 26 октября 2016 г.).

\section{Результаты и обсуждения}

На водоразделе рек Караозен и Сарыозен располагаются два соленых озера - Улкен Тузды Саркыл (ранее Большой Соленый Сакрыл) и Кише Тузды Саркыл (ранее Малый Соленый Сакрыл). Они известны у местного населения под названием Едильбайсор и представляют собой огромные пересохшие замкнутые соленые котловины, заполняемые только талыми весенними водами [28]. По берегам озера Улкен Тузды Саркыл, а также по дну впадающих в него оврагов выходит ряд родников, но количество доставляемой ими воды очень невелико и далеко не покрывает испарение, поэтому большая часть года озеро пересыхает.Большую часть года соленая вода держится лишь изолированными друг от друга мелкими участками.

Озеро Улкен Тузды Саркыл (ранее назывался Большой Сакрыл, Большой Соленый Сакрыл) находится на 30 км северо-западнее поселка Жалпактал и 25 км восточнее районного центра Казталовка Казталовского района Западно-Казахстанской области Республики Казахстан и на 50 км юго-восточнее поселка Александров-Гай АлександровоГайского района Саратовской области Российской Федерации на правом берегу р. Караозен (р.Большой Узень в РФ).Площадь озера Улкен Тузды Саркыл около 260 кв. км, при диаметре (с востока на запад) около 15 км. Берега довольны высоки и местами достигают 12-15 м, но между коренным берегом и дном вокруг всего озера проходит небольшая терраса, высотой 25 м [28].ОзероКише Тузды Саркыл(ранее Малый Сакрыл) располагается в полукилометре южнее от озера Улкен Тузды Саркыл. Площадь озера Кише Тузды Саркыл -70 кв. км. Берега низкие, не превышающие 5-6 м [28].

В юго-восточной части озераУлкен Тузды Саркылрасполагается полуостров, вытянутый параллельно берегу и соединенный с ним узким перешейком. К югу от полуострова находятся три небольших островка. На этих островках и полуострове располагается целая серия газовых источников, издавна привлекавших к себе внимание многочисленных исследователей $[10,11,27,28]$.

Грязь и вода озера Улкен Тузды Саркыл обладают целебными свойствами. Используется для лечения заболеваний суставов. По легенде в 19 веке в данном озере в течении трех дней принимал лечебные процедуры Жангир хан (хан Букеевской орды (1823-1845)), прибыв на озеро на трех парах конных телег. В Казталовском, Жанажолском сельских округах района, где расположено соленое озеро, обитают большое количество людей из одноименного казахского рода «Едилбай» и разводят овец эдильбаевской породы.Эдильбаевская порода овец была выведена в XIX веке в Российской Империи (на территории нынешнего Казахстана) путём скрещивания казахских курдючных овец с грубошёрстными баранами из Астраханской губернии.

По сведениям С. М. Киселева [10], на острове под четвертичными отложениями на глубине примерно 20 м были вскрыты плотные, темно-серые глины акчагыла. Апшеронские осадки в разрезах скважин встречены не были. Очевидно, полуостров соответствует развивающейся положительной структуре, на своде которой развиты акчагыльские осадки. В 
поисковых скважинах, заложенных вблизи естественных газовых выходов, были отмечены газопроявления. Насыщенная газом вода была получена из галечника, находящегося в кровле акчагыльского яруса.

Первая группа газовых выходов обнаружена на северной окраине полуострова (рис.1). Здесь располагается до десятка неглубоких воронок, со дна которых бьют родники соленой воды. Дно воронок покрыто разнозернистым песком с кремневыми и кварцевыми гальками. Родники слабые. Газопроявления незначительные [15].

Вторая группа газовых источников сосредоточена в центральной части полуострова, близ его западного берега. На этом участке найдены полузасыпанные воронки, некогда являвшиеся источниками горючего газа. Местами эти воронки залиты водой. В настоящее время газовые источники второй группы бездействуют [15].

Большое число полузасыпанных и заболоченных газовых источников обнаружено в южной части полуострова. Они образуют третью группу источников. Все источники, бездействующие [15].

Четвертая группа газовых источников расположена в пределах наиболее крупного западного острова. Здесь имеется шесть небольших углубления и одна крупная и глубокая воронка. С углублениями связаны весьма слабые выделения горючих газов. Из глубокой воронки периодически вырываются крупные пузыри горючего газа (рис.2 и 3).

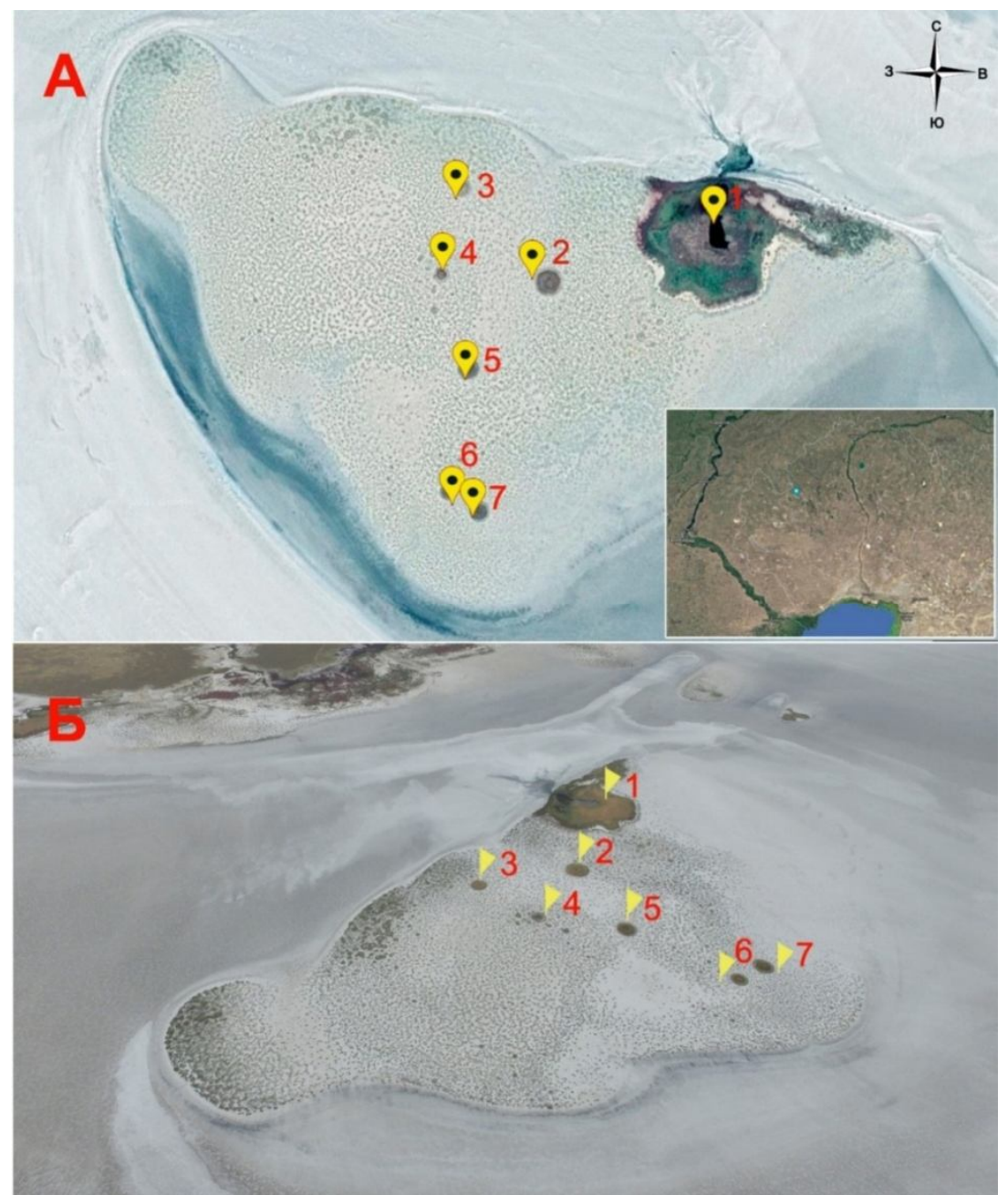

Рисунок 2 - Карта-схема района работ. Схема расположения газовых выходов на западном острове оз. Улкен Тузды Саркыл: A - на космоснимке Google; Б- на снимке с высоты с помощью квадракоптера, 1-7 - номера газовых выходов 


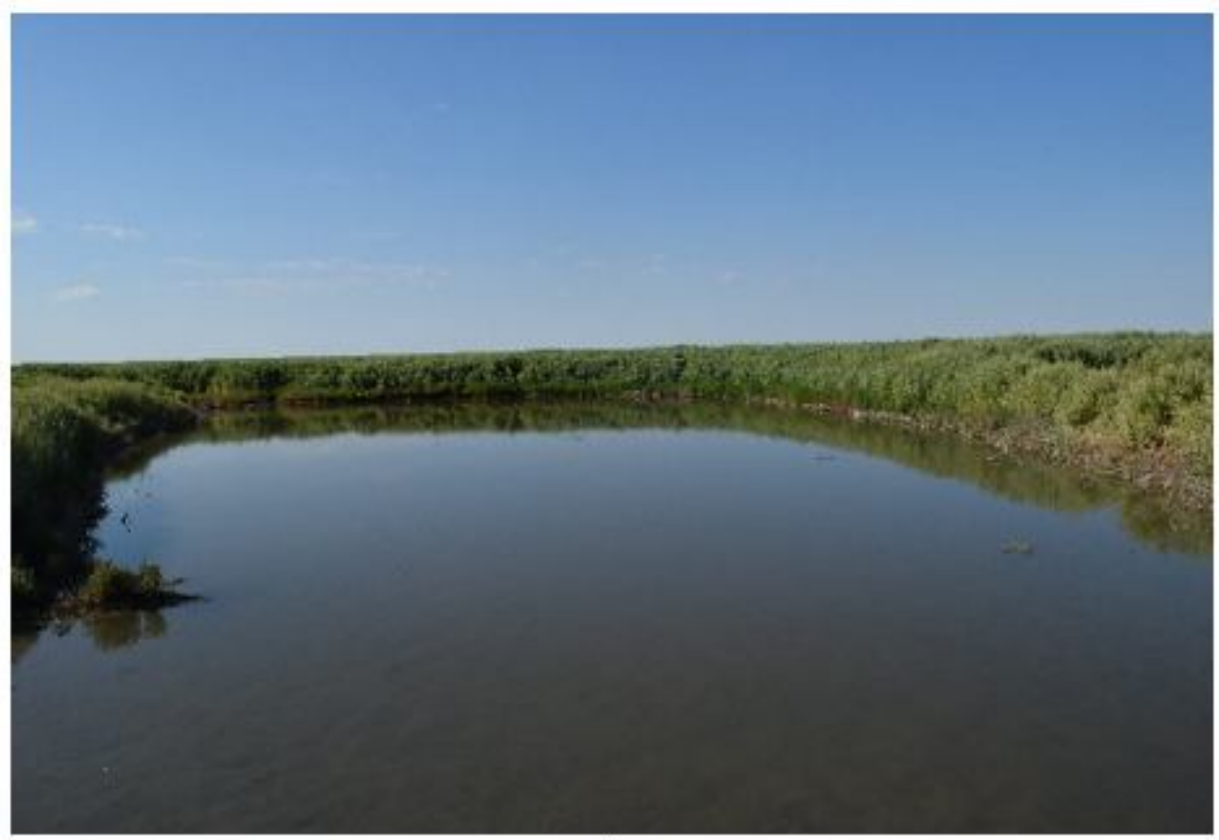

A

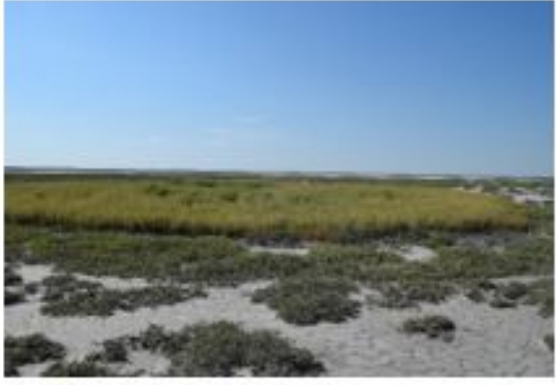

Б

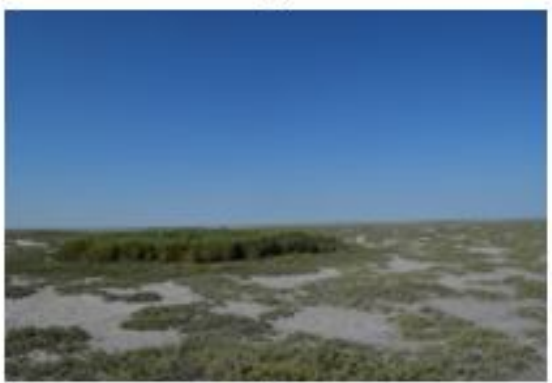

「

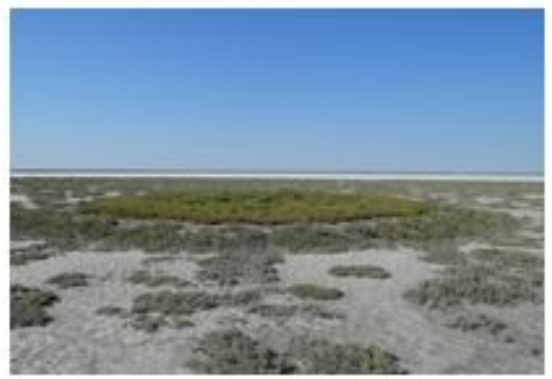

E

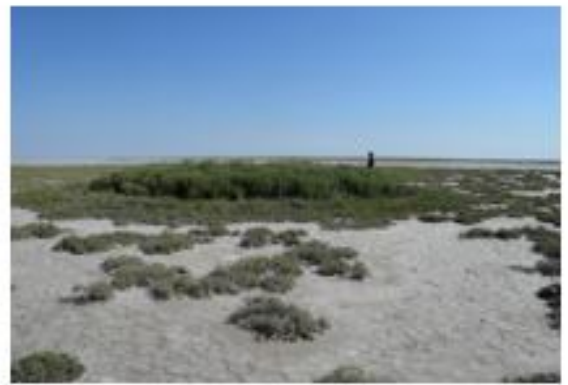

B

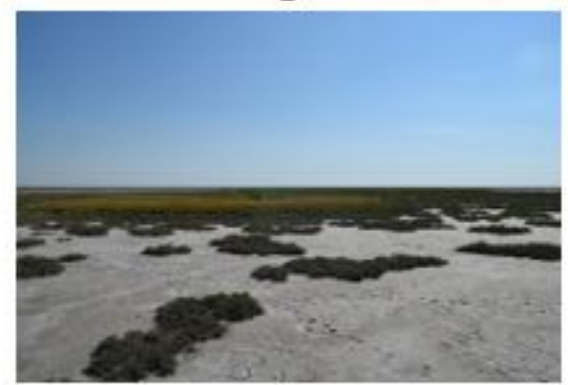

Д

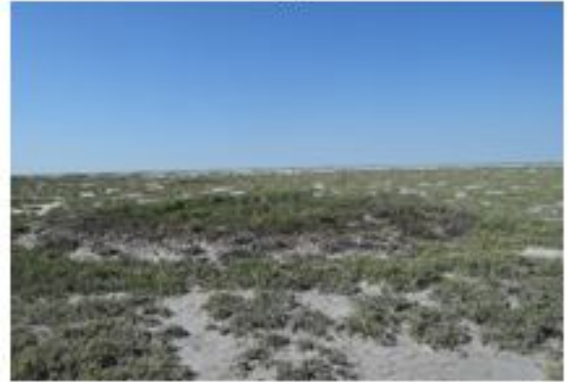

ж

Рисунок 3 - Газовые выходы: А- газовый выход №1; Б- газовый выход №2;

В -газовый выход №3; Г- газовый выход №4; Д - газовый выход №5; E - газовый выход №6; Ж - газовый выход №7 
На соседнем к востоку островке имеется много бездействующих и один небольшой действующий газовые выходы. Газовые источники наблюдаются не только на поверхности острова, они встречены также за пределами последнего, к северу от него, непосредственно на дне озера. Это - пятая группа источников[15].

Шестая группа газовых источников в виде небольших газоводяных родников располагается в пределах крохотного островка в юго- восточном углу оз. Улкен Тузды Саркыл. Здесь, наряду с действующими, имеется большое число затухших газовых выходов. Некоторые из действующих источников выделяют довольно значительное количество горючего газа[15].

Нами в 2021 году была изучена четвертая группа газовых источниковв пределах наиболее крупного западного островаозера Улкен Тузды Саркыл (рис.2 и 3, таблица 1).

Таблица 1 - Характеристика газовых выходов озера Улкен Тузды Саркыл

\begin{tabular}{|c|c|c|c|}
\hline $\begin{array}{l}\text { Номер } \\
\text { выхода }\end{array}$ & Координаты & $\begin{array}{l}\text { Высота } \\
\text { над } \\
\text { уровнем } \\
\text { моря }\end{array}$ & Растительное сообщество \\
\hline 1 & $\begin{array}{l}\text { N } 49^{\circ} 45^{\prime} 56.2^{\prime \prime} \\
\text { E } 49^{\circ} 03^{\prime} 37.3^{\prime \prime}\end{array}$ & 20 & $\begin{array}{c}\text { Галофильное сообщество, представленное } \\
\text { Atriplex tatarica, Atriplex aucheri Moq. Halimione } \\
\text { verrucifera, Oxybasis rubra, Atriplex cana }\end{array}$ \\
\hline 2 & $\begin{array}{l}\mathrm{N} 49^{\circ} 45^{\prime} 54.4^{\prime \prime} \\
\mathrm{E} 49^{\circ} 03^{\prime} 27.8^{\prime \prime}\end{array}$ & 6 & $\begin{array}{c}\text { Галофильное сообщество, представленное Suaeda } \\
\text { acuminata (C.A. Mey.) Moq., Salicornia perennansWilld., } \\
\text { Limonium gmelinii (Willd.) O. Kuntze, Petrosimonia } \\
\text { oppositifolia (Pall.) Litv. Halocnemum strobilaceum (Pall.) } \\
\text { Bieb.) и т.д. }\end{array}$ \\
\hline 3 & $\begin{array}{l}\text { N } 49^{\circ} 45^{\prime} 56.9^{\prime \prime} \\
\text { E } 49^{\circ} 03 ' 23.7^{\prime \prime}\end{array}$ & 9 & $\begin{array}{c}\text { Галофильное сообщество, представленное Frankenia } \\
\text { hirsutaL., Atriplex aucheriMoq. }\end{array}$ \\
\hline 4 & $\begin{array}{l}\text { N } 49^{\circ} 45^{\prime} 54.5^{\prime \prime} \\
\mathrm{E} 49^{\circ} 03^{\prime} 23.0^{\prime \prime}\end{array}$ & 17 & $\begin{array}{c}\text { Галофильноесообщество, представленное Atriplex } \\
\text { cana,Halimione verrucifera, Anabasis salsa }\end{array}$ \\
\hline 5 & $\begin{array}{l}\text { N } 49^{\circ} 45^{\prime} 50.9^{\prime \prime} \\
\text { E } 49^{\circ} 03^{\prime} 24.1^{\prime \prime}\end{array}$ & 9 & $\begin{array}{c}\text { Галофильное сообщество, представленное Atriplex } \\
\text { aucheriMoq. Salicornia europaea L. Salicornia prostrata, } \\
\text { Suaeda linifolia, Suaeda acuminata }\end{array}$ \\
\hline 6 & $\begin{array}{l}\mathrm{N} 49^{\circ} 45^{\prime} 46.7^{\prime \prime} \\
\mathrm{E} 49^{\circ} 03^{\prime} 23.3^{\prime \prime}\end{array}$ & 11 & $\begin{array}{c}\text { Галофильноесообщество, представленное Suaeda } \\
\text { acuminata, Suaeda salsa, Suaeda corniculata. Climacoptera } \\
\text { crassa }\end{array}$ \\
\hline 7 & $\begin{array}{l}\mathrm{N} 49^{\circ} 45^{\prime} 46.3^{\prime \prime} \\
\mathrm{E} 49^{\circ} 03^{\prime} 24.4^{\prime \prime}\end{array}$ & 11 & $\begin{array}{c}\text { Галофильное сообщество, представленное Atriplex cana, } \\
\text { Salicornia europaea L. }\end{array}$ \\
\hline
\end{tabular}

Газовые выходы № 1,2,5,6 имели на поверхности различные объемы воды, выходы №3,4,7 были высохшие (рис.4).Действующими выходами являются 3 выхода (№1, №2и №3), остальные 4 затухшие газовые выходы.Наиболее крупный и глубокий газовый выход это №1 (рис.3А), площадь его около 50 кв. метров. Он заполнен минерализованной водой, глубина около 50-80 см. На газовых выходах №1, №2, №3 на поверхность воды выделяются периодически крупные пузыри газа (рис.4А). 


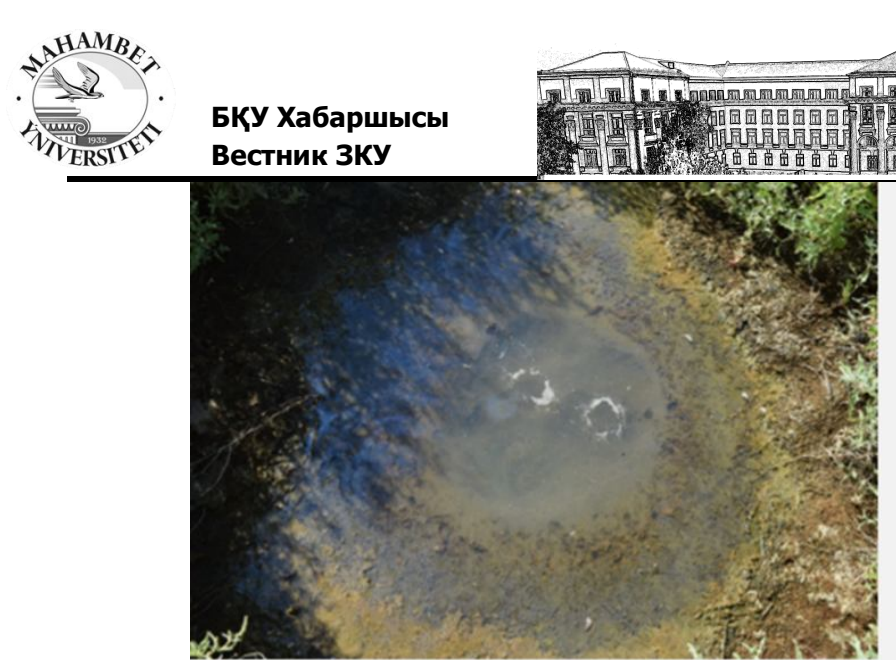

A

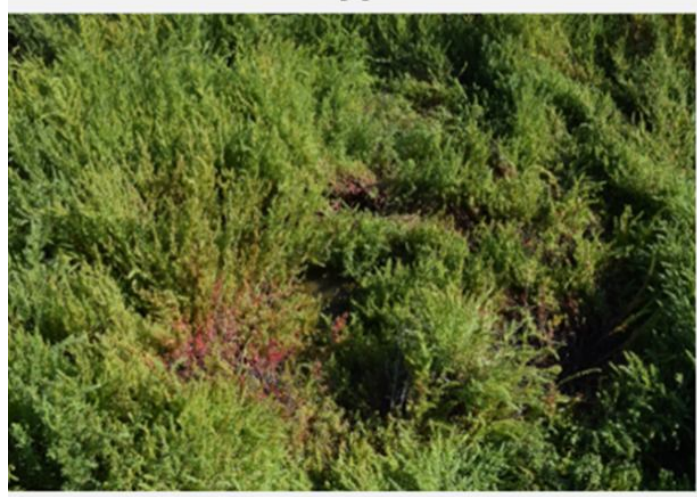

B

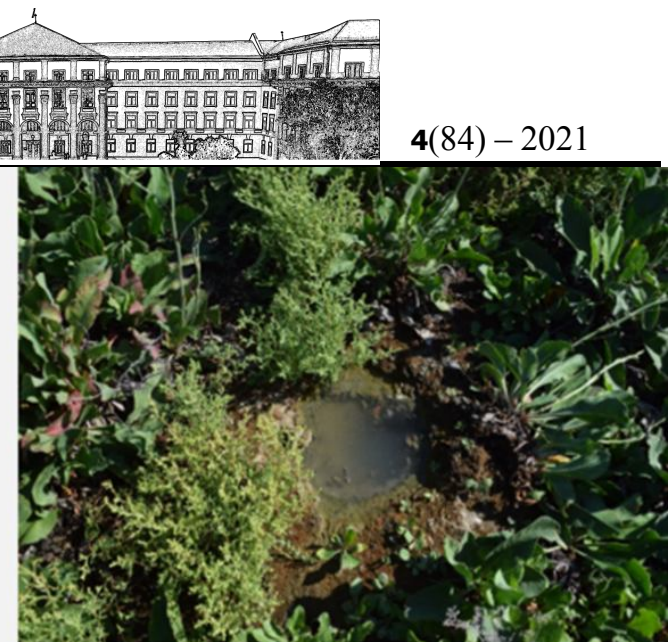

Б

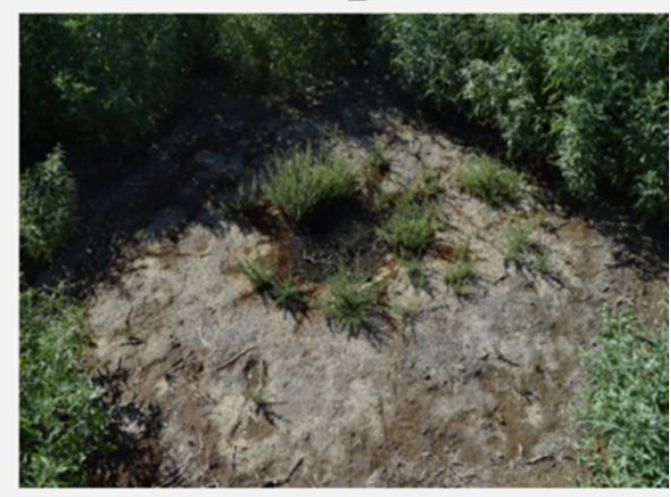

$\Gamma$

Рисунок 4 - Газовые выходыл: А- газовый выход №2; Б- газовый выход №5; В -газовый выход №6; $Г-$ газовый выход №4

Сведения о химическом составе газа $[10,11,15,29]$ приведены в табл. 2. Неглубокозалегающие плиоценовые отложения характеризуются региональной газоносностью. В составе газов, выделявшихся с данных газовых выходов, главным компонентом был метан с некоторой примесью азота. Содержание тяжелых углеводородов невелико и составляло десятые доли процента. Также незначительным являлось содержание углеводородов С2-C5 в ряде образцов метановых газов из естественных выходов (менее 0,1 \%) (табл. 2)

Таблица 2 - Состав газов естественного выхода Улкен Тузды Саркыл, \%

\begin{tabular}{|l|l|l|l|l|l|l|l|l|l|}
\hline $\begin{array}{l}\text { Источник } \\
\text { данных }\end{array}$ & $\mathrm{CO}_{2}$ & $\mathrm{CH}_{4}$ & $\mathrm{C}_{2} \mathrm{H}_{6}$ & $\mathrm{C}_{3} \mathrm{H}_{8}$ & $\mathrm{C}_{4} \mathrm{H}_{10}$ & $\mathrm{~N}_{2}$ & $\mathrm{He}$ & $\mathrm{Ar}$ & $\mathrm{CO}$ \\
\hline $\begin{array}{l}\text { по Мерчева и } \\
\text { др.,2011 [29] }\end{array}$ & 0.7 & 63.3 & 0.002 & 0.001 & 0.003 & 35.5 & 0.017 & 0.50 & - \\
\hline $\begin{array}{l}\text { по Васильеву, } \\
\text { Обрядчикову, } \\
1962 \text { [15] }\end{array}$ & 2.0 & 79.2 & - & - & - & 18.6 & - & - & 0.2 \\
\hline
\end{tabular}

По данным 1928 года анализы проб газа показали следующие результаты (в объемных процентах): метан - 79,2, азот и редкие газы - 18,6, углекислый газ - 2,0, угарный газ - 0,2, сероводород - следы [21]. Для естественных выходов характерно крайне незначительное содержание тяжелых углеводородов. В газах, выделявшихся из плиоценовых отложений, содержание азота было значительным: 18.6-35.5 \%. В пробах газов наблюдалось присутствие сероводорода (следы) [30-32]. Наличие в газе гелия, содержание которого составляет 0.017\%, 
т.е. в количестве, очень близком к концентрации его в воздухе $(0.0023 \%)$, указывает на то, что этот газ сингенетический [33]. Отсутствие тяжелых углеводородов в газе очевидно объясняется геохимической молодостью неогенового бассейна, в котором процессы преобразования органики находятся на начальной стадии и протекают в основном по газовому ряду [34].

В таблице 3 приведены результаты гидрохимических анализов воды из газового выхода №1. По водородному показателю $(\mathrm{pH})$ родниковая вода из газового выхода №1 озера Улкен Тузды Саркыл относится к слабощелочной $(8,03-8,19)$. По минерализации согласно классификации подземных вод по величине общей минерализации (по С.Л. Шварцеву) [35] вода из газового выхода №1 озера Улкен Тузды Саркыл относится к классу соленые к подклассу слабосоленые (таблица 3 ).

Таблийа 3 - Гидрохимические показатели воды газового выхода №1

\begin{tabular}{|c|c|c|c|c|c|c|c|c|c|c|c|}
\hline \multirow{2}{*}{$\begin{array}{c}\text { Дата } \\
\text { отбора }\end{array}$} & \multirow{2}{*}{$\mathrm{pH}$} & $\begin{array}{c}\text { Минера- } \\
\text { лизация, } \\
\text { г/л }\end{array}$ & \multicolumn{7}{|c|}{ Катионно-анионный состав, г/л } \\
\cline { 4 - 12 } & $\mathrm{Ca}^{2+}$ & $\mathrm{Mg}^{2+}$ & $\mathrm{Na}^{+}$ & $\mathrm{K}^{+}$ & $\mathrm{CO}_{3}^{2-}$ & $\mathrm{HCO}_{3}^{-}$ & $\mathrm{Cl}^{-}$ & $\mathrm{NO}_{3}^{-}$ & $\mathrm{SO}_{4}^{2-}$ \\
\hline 03.07 .21 & 8,0 & 15,8 & 0,21 & 0,39 & 1,25 & 0,04 & 0,04 & 0,96 & 3,4 & 0,04 & 0,06 \\
\hline 01.09 .21 & 8,2 & 17,7 & 0,18 & 0,57 & 1,13 & 0,06 & 0,01 & 0,06 & 9,1 & 0,05 & 0,12 \\
\hline
\end{tabular}

По классификации солёности вод по А.М. Овчинникову [36] родниковая вода из газового выхода №1 озера Улкен Тузды Саркыл относится к типу соленые классу воды повышенной солёности. По классификации природных вод по преобладающему аниону и катиону, и соотношению между главнейшими ионами по О.А. Алекину $[37,38]$ вода из газового выхода №1 озера Улкен Тузды Саркыл относится к хлоридному классу, группе натрия, третьему типу.

Для общей характеристики химического состава воды используют широко распространенную формулу Курлова[39,40], часто применяемая для минеральных вод. В летней пробе воды из источника (03.07.2021 г.) вода была хлоридно-гидрокарбонатнонатриево-магниевая (1), в осенней пробе (01.09.2021г.) хлоридно-натриево-магниевая (2).

$$
\begin{aligned}
& \mathrm{M} 15,8 \frac{\mathrm{Cl}_{85 \mathrm{HCO}_{3} 14}}{\mathrm{Na} 56 \mathrm{Mg} 33 \mathrm{Ca} 11} \mathrm{pH} 8,03 \\
& \mathrm{M} 17,7 \frac{\mathrm{Cl99}}{\mathrm{Na} 46 \mathrm{Mg} 44} \mathrm{pH} 8,19
\end{aligned}
$$

Хлоридно-гидрокарбонатно-натриево-магниевый $\quad$ и $\quad$ хлоридно-натриево-магниевый тип минерализации указывает на то, что высокоминерализованные воды по формированию химического состава связаны с процессами континентального засоления, получающими особое развитие на участках бессточных понижений, к которым относится озеро Улкен Тузды Саркыл, дренирующей окружающую местность на хвалынской равнине Прикаспийской низменности. 
Озерные депрессии, вкрапленные среди бессточной равнины Волго-Уральского междуречья, обуславливают сохранение в регионе высокого биотопического и, вследствие этого, видового и экосистемного разнообразия. По побережьям соленых озер и соров, берегам соленых речек, по балкам и древним протокам, формируются разнообразные водные и околоводные сообщества, пионерные, луговые, степные, пустынные и древесно-кустарниковые экосистемы. Особую роль играют околоводные экотоны - природные комплексы переходных территорий, сформированные биогеосистемами разного типа и ранга [41].

Развитие газовых выходов, сформировали на озере Улкен Тузды Саркыл специфический морфоструктурный элемент ландшафта - фацию маревых на солончаке. Его основной особенностью является формирование в аридных условиях особого типа литологической основы с высоким солесодержанием, которое приводит к интенсивному процессу галофитизации местных ландшафтов. Это является основной причиной более плотного распространения, по сравнению с окружающей территорией, солелюбивой растительности - галофильных и гипергалофильных сообществ. Данные ландшафты выделяют в группу «солончаковые супераквальные ландшафты» [42]. Формируемые ландшафты некоторым образом сходны с грязевулканическими ландшафтами [43-45].

Ландшафты непосредственно самих газовых выходов, обладая специфической внутренней динамикой, отличаются от ландшафтов территорий, в пределах которых они расположены. Одной из главных причин этого является тот факт, что ландшафты территорий, прилегающих к газовым выходам, сформировались за относительно длительное время, а формы рельефа газовых выходов и ландшафты на них являются более молодыми образованиями, подвергающимися периодическим изменениям в связи с дебитом воды в них.Формирование ландшафтов на газовых выходах происходит в зависимости от наличия дебита и солености воды, затопления соров в весенний период и высыхания в летний.

Ландшафты газовых выходов очень примитивны. Воронки газовых выходов немного возвышаются на местности и отличается от окружающей территории светло-зеленым или серо-зеленым цветом. Растительные сообщества с участием щирицевых(Amaranthaceae) на сорах и солончаковых котловинах очень оригинальны. Часто они являются «строителями» формации [46], в которых их участие в таксономическом и ценотическом плане очень велико. Кроме того, распределение видов в зависимости от водного режима и солевого баланса солончаков нередко носит концентрический характер, хорошо описанный на примере растительности Эльтонской котловины [47]. На исследованных нами газовых выходах сформировались сплошные заросли видов семейства Щирицевые (Amaranthaceae). Например, Atriplex aucheri, Atriplex tatarica, Oxybasis rubra на газовых выходах развивает кусты высотой до 1,5-2 м.

Основной фон вокруг газовых выходов составляют сарсазановые гипергалофильные сообщества на корковом солончаке (Halocnemum strobilaceum (Pall.) Bieb.) с группами однолетних галофитов, представленных такими видами как: Climacoptera crassa, Ofaiston monandrum, Salicornia prostrata, Suaeda linifolia, Suaeda acuminata.

На самих газовых выходах формируются однолетнесолянковые сообщества на мокрых солончаках и солонцах. Набор видов не велик (Salicornia perennans, Atriplex aucheri, A. tatarica, Suaeda acuminata, Suaeda salsa, Suaeda corniculata, Petrosimonia oppositifolia, Frankenia hirsuta, Limonium gmelinii и т.д.). При этом можно отметить, что более старые коренные сообщества связаны с сообществами Anabasis salsa, более молодые сообщества Halimione verrucifera, Atriplex aucheri, A. tatarica, Oxybasis rubra.

\section{Заключение}

Развитие газовых выходов на озере Улкен Тузды Саркыл привело к формированию специфического морфоструктурного элемента ландшафта, который по своим геохимическим особенностям резко выделяется на фоне окружающих его естественных ландшафтов. Его характерным признаком является избыточное содержаниесолей, которые, поступая на 
поверхность, приводят к формированию литогенной основы с высоким солесодержанием и более интенсивному развитию на ней по сравнению с окружающими территориями галофитной растительности (виды семейства Щирицевые (Amaranthaceae)). Данный тип микроландшафта локализуется на ограниченной территории, прилегающей к конусам газовых выходов. Он отличается своей эндемичностью, редкостью, нестабильностью, а также легкотеряемостью.

Большинство газовых выходов расположено вдали от немногочисленных населенных пунктов. Наверно благодаря этому фактору ни сами газовые выходы, ни их ландшафты не испытывают на себе влияния человеческой деятельности, кроме рекреационнобальнеологического использования. Газовые выходы играют определенную роль в формировании и изменении рельефа. Это образование миниозер, появление таких единиц как родниковые выходы, формирование примитивных микроландшафтов.

Таким образом, комплексное исследование газовых выходов, как элементов ландшафта, весьма важное направление исследований географической науки, а газовые выходы - носители огромной познавательной информации о недрах. Изучение газовых выходов позволяет разобраться во многих теоретических и практических вопросах ландшафтоведения, геологии и геохимии, выяснить строение глубоких горизонтов, происходящих геохимических процессов, что необходимо для решения практических задач вопросов оценки нефтегазоносности больших глубин.

\section{ЛИТЕРАТУРА}

[1]Рашидов Т.М. Грязевые вулканы Азербайджана: морфологические особенности, классификация и геориски // «Современные проблемы геологических наук»: Сб. научных трудов посвященный 155 -летию со дня рождения академика Павла Аполлоновича Тутковского - К., 2013. - С.114-121.

[2]Rashidov T. Morphostructural indicators of oil-and-gas content of mud volcanic edifices from the example of Gobustan and the adjacent territories, South-Caspian basin //Stratigraphy and sedimentology of oil-gas basins. -1.-2021.- 36-51

[3]Шакиров Р.Б. Газогеохимические поля окраинных морей Восточной Азии / Шакиров Р.Б. // - М.: ГЕОС, 2018. - 341 с.

[4]Makarov M. M., Muyakshin S. I., Kucher K. M., Aslamov I. A., Gnatovsky R. Y., Granin N. G. Bubble gas escapes from the bottom of Lake Baikal, dependence of gas flare height on methane flux // Фундаментальная и прикладная гидрофизика. - 2016. - Т. 9. - № 3. -С. $32-41$.

[5]Гранин Н.Г. Газовые гидраты и выходы газов на Байкале / Гранин Н.Г., Гранина Л.3. // Геология и геофизика. - 2002, - 43(7). -С. 629 - 637.

[6]Granin N.G. Gas seeps in Lake Baikal-detection, distribution, and implications for water column mixing / Granin N.G., Makarov M.M., Kucher K.M., Gnatovsky R.Y. - Geo-Marine Letters. - 2010. - 30 (3-4). - C. 399-409.

[7]Granin N.G. Estimation of Methane fluxesfrom bottom sediments of lake Baikal. / Granin N.G., Muyakshin, Makarov M.M., Kucher K.M., Aslamov I.A., Granina L.Z., Mizandrontsev I.B. Geo-Marine Letters. - 2012. - 32(5). - C. 427-436. DOI 10.1007/s00367-012-0299-6

[8]Бузик А.П. О признаках газоносности и нефтеносности в районе Новой Казанки [к югу от верх. р. М. Узень] и Урало-Эмбы / Бузик А.П.// Нижнее Поволжье. - 1929. - № 10. - С. 83-88.

[9]Казаков М.П. Тектоническое строение и история развития Прикаспийской впадины и смежных областей в связи с вопросами нефтегазоносности / Казаков М.П., Чарыгин М.М., Быков Р.И. и др. // - М.: Гостоптехиздат, 1958. - 403 с.

[10] Киселев С.М. Нижнее Заволжье. [Естествен.газы] / Киселев С.М. // Природные газы СССР. Л.-М., ОНТИ, 1935. - С. 110- 148. 
[11]Черепенников А.А. Обследование природных газов в районе Новой Казанки, Уральского округа /Черепенников А.А. //Вестник Геологического Комитета. - № 9-10. - 928.

[12] Брюханов В.Н. О перспективах газоносности верхнеплиоценовых отложений Северного Прикаспия / Брюханов В.Н., Кузьмин Ю.Я. - Геология нефти и газа.- №5.-1960 Москва. - С. 20-25.

[13]Зонн И.С. Каспийское море. / Зонн И.С., Костяной А.Г., Косарев А.Н., Жильцов С.С. - Энциклопедия. - М.: Восточная книга, 2013. - С.148-149.

[14]Михеев В.А. Гидрология. Учебное пособие по курсу "Науки о Земле" для студентов, обучающихся по специальности 28020265 "Инженерная защита окружающей среды"/ Михеев В.А.//. - Ульяновск: УлГТУ, 2010. - 200 с.

[15]Васильев Ю.М., Обрядчиков О.С. Перспективы газонефтеносности плиоценовых отложений Прикаспийской впадины. - Гос.науч.-техн.изд-во нефтяной и горно-топливной литературы / Васильев Ю.М., Обрядчиков О.С. - Москва, 1962.- 180 с.

[16] Ахмеденов К.М. Родники Западного Казахстана как перспективные объекты религиозного туризма /Ахмеденов К.М., Идрисова Г.3. - Вестник ЗКГУ. №2. - Уральск, 2019. - C.462-475

[17]Akhmedenov K. M. Tourist and recreational potential of the salt lakes of Western Kazakhstan /Akhmedenov K. M. // GeoJournalof Tourism and Geosites. - 2020.- 30(2spl). - 782787. https://doi.org/10.30892/gtg.302sp101-505.

[18] Akhmedenov, K.M. Salt lakes of the West Kazakhstan region as objects of medical tourism /Akhmedenov, K.M., Khalelova, R.A.// GeoJournal of Tourism and Geosites. -2021.36(2spl). - 637-645. https://doi.org/10.30892/gtg.362spl11-693.

[19] Шперк Ф. Ф. Букеевская или внутренняя киргизская орда / Шперк Ф. Ф. // Энциклопедический словарь Брокгауза и Ефрона. Том IVA. Санкт-Петербург, ТипоЛитография И.А.Ефрона. - 1891. - 866-871.

[20] Россия. Полное географическое описание нашего Отечества: настольная и дорожная книга для русских людей (1903). / под ред. В. П. Семенова. Санкт-Петербург: издание А.Ф. Девриена, Т. 18: Киргизский край: [Уральская, Тургайская, Акмолинская и Семипалатинская области] / сост. А. Н. Седельников [и др.]. - 478 с.

[21] Тихонович Н.Н. Месторождения естественных горючих газов Нижне-Волжского края и их промышленное значение. - Нижнее Поволжье. - №6.-1928.- С. 135-148.

[22] Западно-Казахстанская область: географическая карта [Карта] / сост. и подгот. к печати РГКП «Национальный картографо-геодезический фонд»; редакторы Е.А. Гесско., А.О. Мамытова., Е.Г. Рынкевич - 1:1 000 000. - Алматы.: РГКП «НКГФ», 2012. - 1 л.

[23] Ландшафтная карта СССР. 1987.- М 1: 2500000 / Под общ. ред. И.С. Гудилина М: ГУГК. 16 Листов.

[24] Доскач А.Г. Природное районирование Прикаспийской полупустыни /Доскач А.Г.// - М.: Наука. - 1979. - 146 с.

[25] Рычагов Г.И. Плейстоценовая история Каспийского моря /Рычагов Г.И.// - М.: Изд-во МГУ -1997. - 267 с.

[26] Ходашова К.С. Природная среда и животный мир глинистых полупустынь Заволжья /Ходашова К.С.// - М.: Изд. АН СССР. - 1960. - 140 с.

[27]Богданов А.А. Соляные купола Нижнего Заволжья / Богданов А.А. // Бюллетень Московского общества испытателей природы.- 12. - 1934. - С.315-367.

[28]Иванов В.В. Физико-географическая характеристика рек Большого и Малого Узеней /Иванов В.В. // Известия Всесоюзного географического общества. -1951. -Вып. 6. C.541-549.

[29] Мерчева В.С. Особенности нефтегазоносности Прикаспийской впадины / Мерчева В.С., Федорова Н.Ф., Серебряков О.И., Красильникова О.В., Серебряков А.О., 


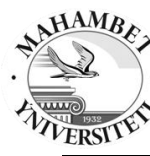

Быстрова И.В., Смирнова Т.С., Лиманский Е.Н.//Геология, география и глобальная энергия. 2011. - № 3 (42). - С.105-112.

[30] Природные газы осадочной толщи / под ред. В. П. Якуцени. - Л.: Недра, Ленинградское отделение, 1976. - С. 46-297.

[31] Пущаровский Ю. М. Геология мантии Земли / Пущаровский Ю. М., Пущаровский Д.Ю. - М.:Геос, 2010. - 140 с.

[32] Соколов В. А. Геохимия природных газов /Соколов В. А.// - М.: Недра, 1971. -

[33] Зорькин Л.М. Гидрогеохимические показатели нефтегазоносности Прикаспийской впадины/ Зорькин Л.М., Стадник Е.В., Козлов В.Г. - М.: Недра. - 1975. -112 c.

[34] Зорькин Л.М., Кричевский Г.Н. О перспективах газоносности и условиях формирования залежей газа неогеновых отложений Прикаспийской впадины /Зорькин Л.М., Кричевский Г.Н. - Труды Всесоюзного научно-исследовательского института природных газов. - Вып.25(33). - М.: Недра. -1965. - С.41-44.

[35] Шварцев С.Л. Общая гидрогеология /Шварцев С.Л.// - М.: Недра. - 1996. - 424 с.

[36] Овчинников А.М. Общая гидрогеология /Овчинников А.M.// - М.: Госгеолтехиздат. - 1955. - 383 с

[37] Алекин О.А. К вопросу о химической классификации природных вод /Алекин O.А. // Вопросы гидрохимии. Тр. НИУ ГУГМС. - 1948. - Cер. IV. - Вып. 32. - С. 25-39.

[38] Алекин О.А. Основы гидрохимии. /Алекин О.А.// - Л.: Гидрометеоиздат. -1970. - 443 c.

[39] Курлов М. Г., Собкевич А.И. Опыт классификации сибирских целебных минеральных вод, согласно химическому их составу [Учен. мед. совет при отделе здравоохранения Сибревкома]. / Курлов М. Г., Собкевич А.И. - Томск: Изд. Том. губ. отд-ния гос. изд-ва. - 1921. -52 с.

[40] Курлов М.Г. Классификация сибирских целебных минеральных вод. / Курлов М.Г. // - Томск: издание Физиотерапевтического ин-та. - 1928. - 74 с.

[41] Новикова Н.М. Достижения и задачи в изучении экотонных систем «вода-суша» / Новикова Н.М. // Аридные экосистемы. - 2006. - Т. 12. - № 30-31. - С. 12-19.

[42] Родикова А.В. О происхождении и свойствах солончаков Хакасии // Вестник Томского государственного университета. - 2007. - Вып. 305. - С. 208-211.

[43] Будагов Б.А. Ландшафты районов развития грязевого вулканизма в Азербайджане / Будагов Б.А., Микаилов А.А., Омарова Х.И //. - Фонд ИГ НАНА, Баку. 1972. - $258 \mathrm{c}$.

[44] Будагов Б.А., Микаилов А.А. Динамика ландшафтов грязевых вулканов Азербайджанской ССР / Будагов Б.А., Микаилов А.А. - Материалы V Съезда Географического Общества Азерб. ССР. -Баку: Элм. - 1985. - С. 2

[45] Холодов В.Н. О природе грязевых вулканов// Природа. - 2002. - №11. - С.47-58.

[46] Freitag H., Golub V.B., Yuritsyna N.A. Halophytic plant communities in the Northern Caspian lowlands: I, annual halophytic communities Phytocoenologia. - 2001. - Vol.31. №1. - P.36-108.

[47] Ильин М.М. Растительность Эльтонской котловины // Изв.Гл. бот. сада. - 1927. т.26. - Вып.4. - С.371-414.

\section{REFERENCES}

[1]Rashidov T.M. (2013). Grjazevye vulkany Azerbajdzhana: morfologicheskie osobennosti, klassifikacija i georiski [Mud volcanoes of Azerbaijan: morphological features, classification and georisk]. «Sovremennye problemy geologicheskih nauk»: Sb. nauchnyh trudov posvjashhennyj 155-letiju so dnja rozhdenija akademika Pavla Apollonovicha Tutkovskogo K.114-121[In Russian]. 

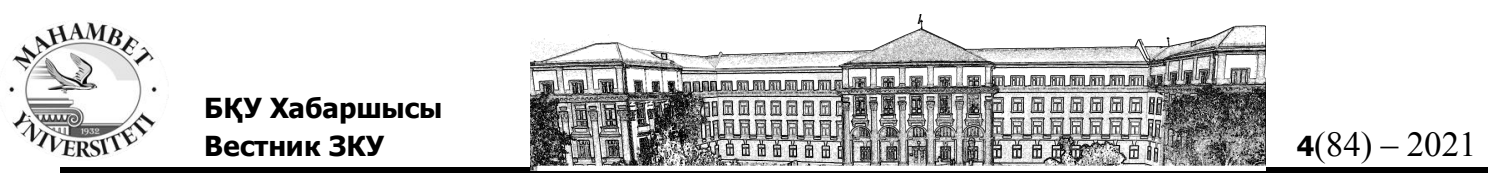

[2]Rashidov T. (2021). Morphostructural indicators of oil-and-gas content of mud volcanic edifices from the example of Gobustan and the adjacent territories, South-Caspian basin //Stratigraphy and sedimentology of oil-gas basins. 1.36-51[In English].

[3]Shakirov R.B. (2018). Gazogeohimicheskie polja okrainnyh morej Vostochnoj Azii [Gasgeochemical fields of the Eastern Asia marginal seas] Moscow: GEOS Publishers. 341[In Russian].

[4]Makarov M.M., Muyakshin S.I., Kucher K.M., Aslamov I. A., Gnatovsky R. Y., Granin N.G. (2016). Bubble gas escapes from the bottom of Lake Baikal, dependence of gas flare height on methane flux. Fundamentalnaya i prikladnaya gidrofizika. 9.3.32-41 [In English].

[5]Granin N.G., Granina L.Z. (2002). Gazovye gidraty i vyhody gazov na Bajkale [Gas hydrates and gas venting in lake Baikal].Geologija i geofizika. 43(7). 629 - 637[In Russian].

[6]Granin N.G., Makarov M.M., Kucher K.M., Gnatovsky R.Y. (2010). Gas seeps in Lake Baikal-detection, distribution, and implications for water column mixing. Geo-Marine Letters. 30 (3-4).399-409 [In English].

[7]Granin N.G., Muyakshin, Makarov M.M., Kucher K.M., Aslamov I.A., Granina L.Z., Mizandrontsev I.B. (2012). Estimation of Methane fluxesfrom bottom sediments of lake Baikal. Geo-Marine Letters. 32(5). 427-436. DOI 10.1007/s00367-012-0299-6 [In English].

[8] Buzik A.P. (1929). O priznakah gazonosnosti i neftenosnosti v rajone Novoj Kazanki [k jugu ot verh. r. M. Uzen'] i Uralo-Jemby [On the signs of gas content and oil content in the area of Novaya Kazanka [south of the top. R. M. Uzen] and Uralo-Emba]. Nizhnee Povolzh'e. № 10. 83-88 [In Russian].

[9] Kazakov M.P., Charygin M.M., Bykov R.I. and etc. (1958). Tektonicheskoe stroenie i istorija razvitija Prikaspijskoj vpadiny i smezhnyh oblastej v svjazi s voprosami neftegazonosnosti [Tectonic structure and history of the development of the Caspian basin and adjacent areas in connection with the issues of oil and gas potential]. M.: Gostoptehizdat. 403 [In Russian].

[10] Kiselev S.M. (1935). Nizhnee Zavolzh'e. [Estestven.gazy] [Lower Trans-Volga region. [Natural Gas]]. In: Prirodnye gazy SSSR. L.- M., ONTI. 110- 148 [In Russian].

[11] Cherepennikov A.A.(1928). Obsledovanie prirodnyh gazov v rajone Novoj Kazanki, Ural'skogo okruga [Inspection of natural gases in the area of Novaya Kazanka, Ural district]. Vestnik Geologicheskogo Komiteta. № 9-10. [In Russian].

[12] Brukhanov V.N., Kusmin Yu.J. (1960). O perspektivah gazonosnosti verhnepliocenovyh otlozhenij Severnogo Prikaspija [On gas possibilities of upper Pliocene deposits of the northern part of Peri Caspian region]. Geologija nefti i gaza.5. Moskva. 20-25 [In Russian].

[13] Zonn I.S., Kostyanoy A.G., Kosarev A.N., Zhiltsov S.S. (2013). Kaspijskoe more. Jenciklopedija [Caspian Sea. Encyclopedia]. M.: Vostochnaja kniga. 148-149 [In Russian].

[14] Mikheev V.A. (2010).Uchebnoe posobie po kursu "Nauki o Zemle" dlja studentov, obuchajushhihsja po special'nosti 28020265 "Inzhenernaja zashhita okruzhajushhej sredy". [Hydrology. Textbook for the course "Earth Sciences" for students studying in the specialty 28020265 "Environmental Engineering"]. Ulyanovsk: U1STU, 200 [In Russian].

[15]Vasiliev Yu.M., Obryadchikov O.S. (1962). Perspektivy gazoneftenosnosti pliocenovyh otlozhenij Prikaspijskoj vpadiny [Prospects for the gas and oil content of the Pliocene sediments of the Caspian Basin]. State Scientific and Technical Publishing House of Oil and Mining and Fuel Literature. Moscow. 180. [In Russian].

[16] Akhmedenov K.M., Idrisova G.Z. (2019).Rodniki Zapadnogo Kazahstana kak perspektivnye ob\#ekty religioznogo turizma [Springs of Western Kazakhstan as promising objects of religious tourism]. Vestnik ZKGU. 2. Uralsk. 462-475. [In Russian].

[17] Akhmedenov K. M. (2020). Tourist and recreational potential of the salt lakes of Western Kazakhstan. GeoJournal of Tourism and Geosites. 30(2spl), 782-787. https://doi.org/10.30892/gtg.302sp101-505 [In English]. 


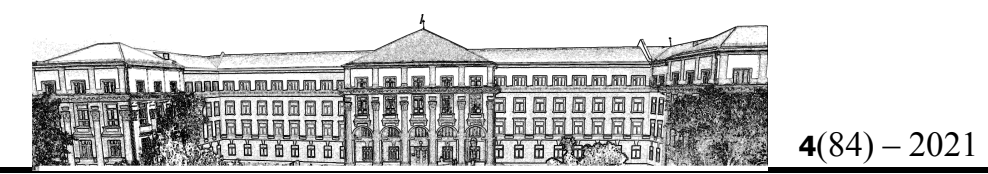

[18] Akhmedenov, K.M., \& Khalelova, R.A. (2021). Salt lakes of the West Kazakhstan region as objects of medical tourism. GeoJournal of Tourism and Geosites, 36(2spl), 637-645. https://doi.org/10.30892/gtg.362sp111-693 [In English].

[19] Shperk F.F. (1891). Bukeevskaja ili vnutrennjaja kirgizskaja orda [Bukeevskaya or internal Kyrgyz horde]. Encyclopedic Dictionary of Brockhaus and Efron. Volume IV A. St. Petersburg, Typo-Lithograph by I.A.Efron. 866-871 [In Russian].

[20] Rossija. Polnoe geograficheskoe opisanie nashego Otechestva: nastol'naja i dorozhnaja kniga dlja russkih ljudej (1903). [Russia. Complete geographical description of our Fatherland: handbook and road book for Russian people] ed. V.P.Semenov. St. Petersburg: A.F. Devriena, T.18: Kyrgyz Territory: [Ural, Turgai, Akmola and Semipalatinsk regions] / comp. A.N. Sedelnikov [and others]. 478 [In Russian].

[21] Tikhonovich N.N. (1928). Mestorozhdenija estestvennyh gorjuchih gazov NizhneVolzhskogo kraja $\mathrm{i}$ ih promyshlennoe znachenie [Deposits of natural combustible gases in the Lower Volga region and their industrial significance] Lower Volga region. 6. 135-148 [In Russian].

[22] Zapadno-Kazahstanskaja oblast': geograficheskaja karta [Karta] (2012). West Kazakhstan region: geographical map [Map] / comp. and prepare. for publication RGKP "National Cartographic and Geodetic Fund"; editors E.A. Gessko., A.O. Mamytova., E.G. Rynkevich - 1: 1 000 000. - Almaty.: RGKP "NKGF". 1 [In Russian].

[23]Landshaftnaja karta SSSR (1987). [Landscape map of the USSR]. M 1: 2500000 / Under total. ed. I.S. Goodilina M: GUGK. 16 Sheets. [In Russian].

[24] Doskach A. G. (1979). Prirodnoye rayonirovaniye Prikaspiyskoy polupustyni [Natural zoning of the Caspian semi-desert]. Moscow, Nauka Publ., 146 [in Russian].

[25] Rychagov G.I. (1997). Plejstocenovaja istorija Kaspijskogo morja [Pleistocene History of the Caspian Sea]Moscow: Publishing house of Moscow State University. 267 [In Russian].

[26] Khodashova K. S. (1960). Prirodnaya sreda i zhivotnyy mir glinistykh polupustyn' Zavolzh'ya [Natural environment and fauna of the clay semi-deserts of the Trans-Volga region]. Moscow, Publishing House of the Academy of Sciences of the USSR. 131[in Russian].

[27] Bogdanov A.A. (1934).Soljanye kupola Nizhnego Zavolzh'ja [Salt domes of the Lower Volga region]. Bulletin of the Moscow Society of Naturalists, 12.315-367 [in Russian].

[28]Ivanov V.V. (1951). Fiziko-geograficheskaja harakteristika rek Bol'shogo i Malogo Uzenej [Physical and geographical characteristics of the rivers of the Big and Small Uzeney]. Izvestiya Vsesoyuznogo geograficheskogo obshchestva [Proceedings of the All-Union Geographical Society], 6, 541-549 [In Russian].

[29] Mercheva V.S., Fedorov N.F., Serebryakov O.I., Krasilnikova O.V., Serebryakov A.O., Bystrova I.V., Smirnova T.S., Limansky E.N. (2011).Osobennosti neftegazonosnosti Prikaspijskoj vpadiny [Peculiarities of oil and gas bearing of the Caspian depression]. Geology, geography and global energy. № 3 (42).105-112. [In Russian].

[30] Prirodnye gazy osadochnoj tolshhi (1976). [Natural gases of sedimentary strata] ed. V.P. Yakutseni. L.: Nedra, Leningrad branch. 46-297. [In Russian].

[31] Pushcharovsky Yu. M., PushcharovskyD.Yu. (2010).Geologijamanti I Zemli [Geology of the Earth's mantle] M.: Geos. 140 [In Russian].

[32] Sokolov V.A. (1971). Geohimija prirodnyh gazov [Geochemistry of natural gases] M.: Nedra. 21-27 [In Russian].

[33] Zorkin L.M., Stadnik E.V., Kozlov V.G. (1975).Gidrogeohimicheskie pokazateli neftegazonosnosti Prikaspijskoj vpadiny [Hydrogeochemical indicators of oil and gas content of the Caspian basin] M.: Nedra. 112 [In Russian].

[34] Zorkin L.M., Krichevsky G.N. (1965). O perspektivah gazonosnosti iuslovijah formirovanij a zalezhej gazaneogenovyh otlozhenij Prikaspijskoj vpadiny [On the prospects of gas content and the conditions for the formation of gas deposits in Neogene deposits of the Caspian 


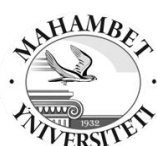

basin] Proceedings of the All-Union Scientific Research Institute of Natural Gases. Issue 25 (33). M.: Nedra. 41-44(In Russian).

[35] Shvartsev S.L. (1996).Obshhaja gidrogeologija [General hydrogeology]. Moscow: Nedra. 424 (In Russian).

[36] Ovchinnikov A.M. (1955). Obshhaja gidrogeologija [General hydrogeology]. M.: Gosgeoltekhizdat. 383(In Russian).

[37] Alekin O.A. (1948). K voprosu o himicheskoj klassifikacii prirodnyh vod [On the question of the chemical classification of natural waters] Questions of hydrochemistry. Tr. NRU GUGMS. Ser. IV. Issue 32. 25-39 [In Russian].

[38] Alekin O.A. (1970).Osnovygidrohimii [Fundamentals of Hydrochemistry] L.: Gidrometeoizdat. 443. [In Russian].

[39] Kurlov M. G., Sobkevich A. I. (1921). Opyt klassifikacii sibirskih celebnyh mineral'nyh vod, soglasno himicheskomuih sostavu [Experience in the classification of Siberian medicinal mineral waters, according to their chemical composition] [Uchen. honey. council at the health department of Sibrevkom]. Tomsk: Ed. Volume. lips. department of state publishing house. 52 [In Russian].

[40] Kurlov M.G. (1928). Klassifikacija sibirskih celebnyhmineral'nyh vod [Classification of Siberian healing mineral waters] Tomsk: edition of the Physiotherapeutic Institute. 74. [In Russian].

[41] Novikova N.M. (2006). Dostizheni jaizadachi v izucheni ijekotonnyh sistem «vodasusha» [Achievements and challenges in the study of ecotonic systems "water-land»] Arid ecosystems. T. 12.No. 30-31. 12-19 [In Russian].

[42] Rodikova A.V. (2007). O proishozhdenii i svojstvah solonchakov Khakassii [On the origin and properties of the salt marshes of Khakassia] Bulletin of the Tomsk State University. Issue. 305.208-211 [In Russian].

[43] Budagov B.A., Mikailov A.A., OmarovaKh.I. (1972).Landshafty rajonov razvitija grjazevogo vulkanizma $v$ Azerbajdzhane [Landscapes of areas of development of mud volcanism in Azerbaijan] IG ANAS Foundation, Baku. 258 [In Russian].

[44] Budagov B.A., Mikailov A.A. (1985). Dinamika landshaftov grjazevyh vulkanov Azerbajdzhanskoj SSR [Dynamics of landscapes of mud volcanoes of the Azerbaijan SSR] Materials of the V Congress of the Geographical Society of the Azerbaijan SSR. Baku: Elm. 2 [In Russian].

[45] KholodovV.N. (2002).O prirode grjazevyh vulkanov[On the nature of mud volcanoes] Nature. 11. 47-58 [In Russian].

[46] Freitag H., Golub V.B., Yuritsyna N.A. (2001). Halophytic plant communities in the Northern Caspian lowlands: I, annual halophytic communities Phytocoenologia.Vol.31. №1. 36-108 [In English].

[47] Ilyin M.M. (1927). Rastitel'nost 'Jel'tonskoj kotloviny [Vegetation of the Elton depression]Izv. Gl. bot. garden. Vol.26. Issue 4. 371-414 [In Russian].

\section{Ахмеденов К.М.}

\section{БАТЫС КАЗАҚСТАН ОБЛЫСЫ ҮЛКЕН ТҰЗДЫ САРКӨЛ КӨЛІНІН ТАБИҒИ}

\section{ГАЗ ШЫҒУЛАРЫ}

Андатпа. Әдеби және табиғи деректер негізінде Батыс Қазақстан облысы Казталов ауданы, Каспий маңы ойпатының солтүстік бөлігінде орналасқан және тұрақты емес деңгейге ие Үлкен Тұзды Саркөлкөлінің шегінде табиғи газ шығулары зерттелді. Үлкен Тұзды Саркөл көлінің батыс аралындағы 7 газ шығысына сипаттама берілді. Өсімдіктер қауымдастықтарының құрамы, гидрохимиялық құрамы және газ шығатын сулардың минералдануы анықталды. Осы газ шығыстарынан бөлінетін газдардың құрамында негізгі компонент азот қоспасы бар метан болды. № 1 газ шығысынан шыққан су сәл сілтілі, тұз 

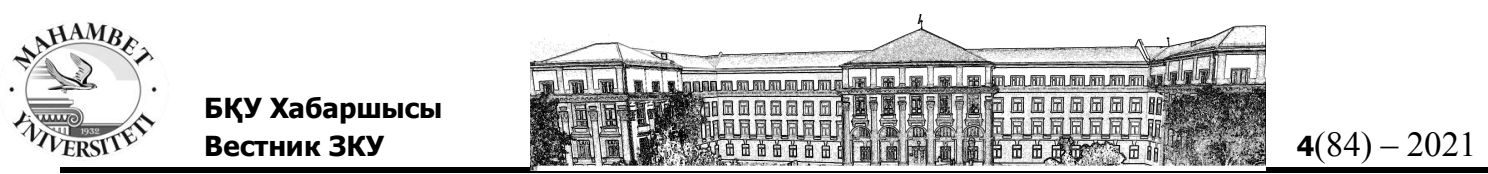

класына жатады, тұздылығы төмен. Хлоридті-гидрокарбонатты-натрийлі-магнийлі және хлоридті-натрийлі-магнийлі су минералдануының түрі химиялық құрамның қалыптасуы бойынша жоғары минералданған сулардың континентальды тұздану процестерімен байланысты екендігін көрсетеді. Газ шығуында галофильді және гипергалофильді өсімдік қауымдастықтары кең таралды.

Құрғақ климат жағдайында газ шығуының қарапайым ландшафттарының қалыптасу ерекшеліктері көрсетілген. Газ шығатын жерлерде ландшафттардың қалыптасуы судың ағуымен тұздылығына, көктемде сорлардың субасуына және жазда кебуіне байланысты жүреді.

Кілт сөздер: табиғи газ шығулары; газдар; газ бөлінулері; тұзды көл; тұзды батпақ; галофильді өсімдік қауымдастықтары; минералдану; ландшафт; бір жылдық тұзды сораңды қауымдастықтар; гидрохимия.

\section{Akhmedenov Kazhmurat \\ NATURAL GAS OUTLETS OF LAKE ULKEN TUZDY SARKYL OF THE WEST KAZAKHSTAN REGION}

Annotation. On the basis of the literary and field data, natural gas outlets were studied within Lake Ulken Tuzdy Sarkyl of Kaztalovsky district of the West Kazakhstan region, located in the northern part of the Caspian lowland and having an unstable level. The characteristics of 7 gas outlets on the western island of Lake Ulken Tuzdy Sarkyl are given. The composition of the plant communities, features of hydrochemical composition and mineralization of gas outlet waters were revealed. As part of the gases emitted from these gas outlets, the main component was methane with some nitrogen admixture. The water from the gas outlet No. 1 is slightly alkaline, belongs to the class salty and to the subclass slightly salted. The chloride-hydrocarbonate-sodium-magnesium and chloride-sodium-magnesium type of water mineralization indicates that highly mineralized waters are associated with the processes of continental salinization by forming a chemical composition. Within the gas outlets, halophilic and hyperhalophilic plant communities have become widespread.

Features of the formation of primitive landscapes of the gas outlets are shown in conditions of arid climate. The formation of landscapes at the gas outlets occurs depending on the presence of flow rate and salinity of water, and also flooding of the salt lakes in spring and drying in summer.

Keywords: natural gas outlets; gases; gas indications; salty lake; salt marsh; halophilic plant communities; mineralization; landscape; one-year-old communities; hydrochemistry. 